\title{
ISATIS ARMENA (BRASSICACEAE), NEW FOR FLORA PALAESTINA
}

\author{
Ori Fragman-SAPIR, Hatem TAIfour \& Jotham Ziffer-Berger ${ }^{1}$
}

\begin{abstract}
We report three records of Isatis armena L. (Brassicaceae) from southwestern Jordan, new for Flora Palaestina. The species, typically of a broad Irano-Turanian distribution, is unprecedentedly reported from the Saharo-Arabian floristic region, nearly $1000 \mathrm{~km}$ remote from its known range.
\end{abstract}

Key words: Cruciferae, distribution, Jordan, new records, Sameraria armena

Ori Fragman-Sapir, Jerusalem Botanical Gardens and the Herbarium, the National Natural History Collections, The Hebrew University of Jerusalem, Edmond J. Safra Campus, Givat Ram, Jerusalem 9021904, Israel; e-mail: fragman@botanic.co.il Hatem Taifour, Royal Botanic Garden, P.O. Box 99, Amman 11910, Jordan; e-mail: htaifour@royalbotanicgarden.org Jotham Ziffer-Berger, Herbarium, the National Natural History Collections, The Hebrew University of Jerusalem, Edmond J. Safra Campus, Givat Ram, Jerusalem 9021904, Israel; e-mail: fragman@botanic.co.il \& jotham.z@mail.huji.ac.il

The genus Isatis L. (Brassicaceae) comprises 79 species, centered in the Irano-Turanian region (Davis 1965; Warwick et al. 2006). According to a recent molecular phylogenetic study, the genus Isatis nests three additional Irano-Turanian genera, namely Sameraria Desv., Pachypterygium Bunge and Tauscheria Fisch., previously regarded as distinct (Moazzeni et al. 2010). Altogether, Isatis sensu Moazzeni et al. encompasses 92 species. In the Flora Palaestina area, two species of Isatis have been reported, namely the MediterraneanIrano-Turanian I. lusitanica L., and the SaharoArabian I. microcarpa Boiss. (Rechinger 1952 - I. lusitanica as I. aleppica Scop.; Davis 1965; Zohary 1966). Here we report first records of Isatis armena L. [synonym Sameraria armena (L.) Desv.] from Jordan (Fig. 1), which are also new records for the whole of the Levant.

The first specimen of I. armena was collected on April $5^{\text {th }} 2014$ by Vered and Ori FragmanSapir at Jabal Umm Ad-Dami (Aqaba Governorate) near the Jordanian-Saudi border, in the phytogeographic district of Edom $\left(29^{\circ} 18^{\prime} 37.35^{\prime \prime} \mathrm{N}\right.$, $35^{\circ} 26^{\prime} 44.28^{\prime \prime}$; Fig. 2) at $1670 \mathrm{~m}$ a.s.1. (125919

\footnotetext{
1 Corresponding author
}

HUJ!, 2015ST030011 Amman!, acronym not assigned). The plant was found growing between rocks on slopes of red sandstone mountains in the desert. The plants were associated with diffuse, low vegetation, among Artemisia sieberi Besser, Gymnocarpos decander Forssk. and Isatis lusitanica L. The species was locally very rare and sporadic, with only two individuals viewed.

Two additional neighboring Jordanian populations were reported by Ya'ir Ur and Mimi Ron in the Ras-en-Naqb area (Edom, Ma'an Governorate), ca $80 \mathrm{~km}$ north of Jabal Umm Ad-Dami. The plants were found on April $23^{\text {rd }} 2015$ at $30^{\circ} 2^{\prime} 48.29^{\prime \prime} \mathrm{N}$, $35^{\circ} 27^{\prime} 1.34^{\prime \prime} \mathrm{E}$ (Naqb 2; Fig. 2) and on May $23^{\text {rd }}$ 2014 at $30^{\circ} 3^{\prime} 40.62^{\prime \prime} \mathrm{N}, 35^{\circ} 26^{\prime} 41.22^{\prime \prime} \mathrm{E}$ (Naqb 1; Fig. 2). At these two sites, I. armena was found as a weed in traditionally managed cereal fields on calcareous bedrock. Seeds from the 'Naqb 1' population were collected and are stored in the seed collection of the Royal Botanic Gardens in Jordan and in the Jerusalem Botanical Gardens (accession nos. 2015ST030010 and JBG2014-0515 respectively).

Isatis armena (Fig. 1) is a glabrous and glaucous annual herb growing up to $30 \mathrm{~cm}$. The racemes bear auriculate leaves at their bases. The 


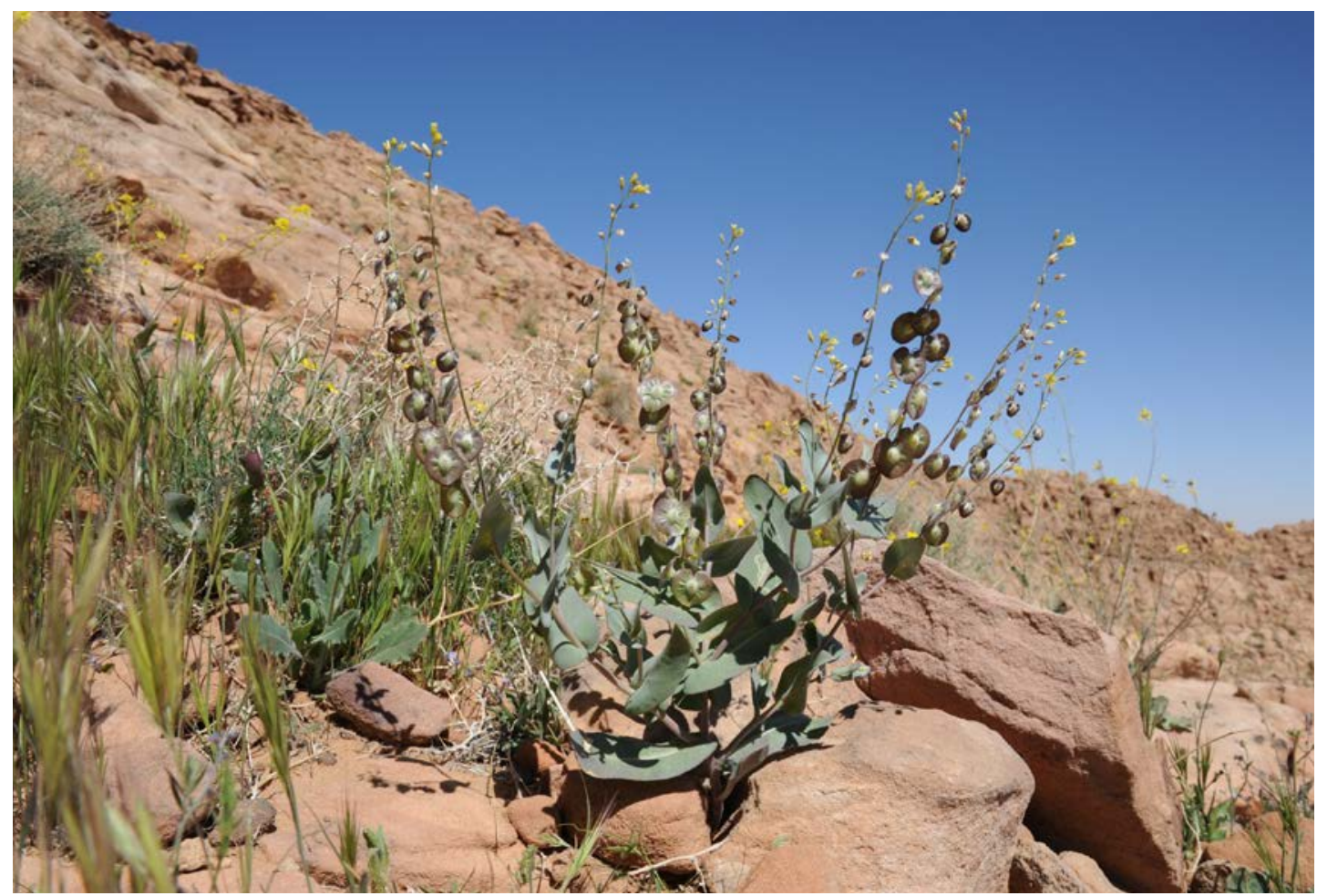

Fig. 1. Isatis armena L. in Jabal Umm Ad-Dami, Jordan. Photo O. Fragman-Sapir.

flowers have erect pedicels, becoming recurved at fruit set. The petals are pale yellow. The fruit is an indehiscent winged discoid silicle $1.2 \mathrm{~cm}$ in diameter, cordate at the base. The silicle surface is tomentose, except for the wing. The 4-5 $\mathrm{mm}$ wide, dark-veined wing encircles the locule. A stylar tip persists at the distal end of the silicle. Isatis armena is distinguished from the sympatric $I$. lusitanica and I. microcarpa by the orbicular silicle and its cordate base.

Seeds were sown at the Jerusalem Botanical Gardens in a net house in October 2014 and germinated only after cold stratification and addition of gibberellic acid. Germination occurred in early January and inflorescences appeared in March. Almost all flowers developed into fruits.

Isatis armena is new for Flora Palaestina area (Israel, the Palestinian Territory and western Jordan) as well as the whole Levant. We presume that the presence of the species is not episodic, since the plant was found in three different localities. The species has a typical Irano-Turanian distribution, and was previously reported from Afghanistan, Pakistan, Iran (Hedge \& Rechinger 1968), North Iraq, Armenia, Turkey, Caucasia (Davis 1965),

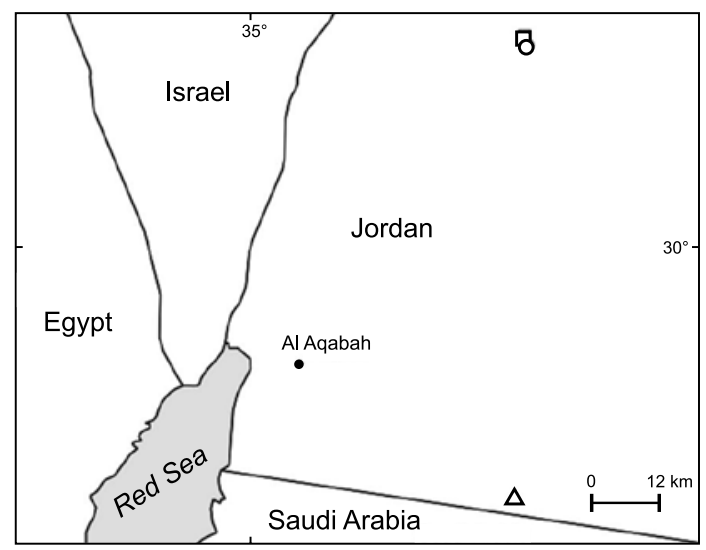

Fig. 2. New locations of Isatis armena L. in Jordan. $\Delta$ - Jabal Umm Ad-Dami, $\square-$ Naqb 1, O - Naqb 2. Retrieved from Shorthouse (2010). 
Azerbaijan and Turkestan (Boissier 1867; Bush \& Vasil'chenko 1970). It has not been reported from any Levantine country (Lebanon, Syria, Jordan and Israel), nor from Arabia. These recent findings from Jordan suggest that the distribution range of $I$. armena is disjunct. This distribution pattern is remarkable not only because of the nearly $1000 \mathrm{~km}$ gap between populations (southwestern Jordan to northern Iraq), but also because of the extension of the species range far beyond of its typical Irano-Turanian floristic region, as Jabal Umm Ad-Dami is located in the Saharo-Arabian floristic region (Shmida et al. 1985).

Further surveys are needed to determine the full range of this species in Jordan and possibly in northern Saudi Arabia, as well as in the gap towards the populations north of the Levant. Due to its rarity, we recommend adding I. armena to the red data book of Jordan.

ACKNowledgements. We thank Ya'ir Ur and Mimi Ron for their invaluable observations, Maya Abutbul and Hans Mackrodt for applying their skills and patience in germinating and growing the plants at the nursery of the Jerusalem Botanical Gardens, Hagar Leschner for commenting on the manuscript, and the anonymous referee for helpful remarks. The financial support for the Jerusalem Botanical Gardens from the Israel Ministry of Agriculture, through the Israeli Botanical Gardens Council, is greatly appreciated.

\section{REFERENCES}

BoISsier E. 1867. Flora orientalis. 1. H. Georg, Basileae.

Bush N. A. \& VAsIL'Chenko I. T. 1970. Sameraria Desv. In: N. A. BusH (ed.), Flora of the USSR. 8: 172-176. Israel Program of Scientific Translation, Jerusalem.

Davis P. H. 1965. Flora of Turkey and the East Aegean Islands. 1. University Press, Edinburgh.

Hedge J. \& Rechinger K. 1968. Flora Iranica: Cruciferae. Akademische Druck- u. Verlagsanstalt, Graz.

Moazzeni H., Zarre S., Al-Shehbaz I. \& Mummenhoff K. 2010. Phylogeny of Isatis (Brassicaceae) and allied genera based on ITS sequences of nuclear ribosomal DNA and morphological characters. Flora 205(5): 337-343.

Rechinger K. H. FIL. 1952. Zur Flora von Palästina und Transjordanien. Reliquiae Samuelssonianae V. Ark. Bot. 2(5): 271-455.

Shmida A., Evenari M. \& Noy-Meir I. 1985. Hot desert ecosystems: an integrated review. In: M. EvENARI, I. NOY-MEIR \& D. W. Goodall (eds.), Hot deserts and arid shrublands. Ecosystems of the World. 12b: 379-387. Elsevier, Amsterdam.

Shorthouse D. P. 2010. SimpleMappr, an online tool to produce publication-quality point maps. [June 2015]. http:// www.simplemappr.net.

Warwick S. I., Francis A. \& Al-Shehbaz I. 2006. Brassicaceae: Species checklist and database on CD-Rom. Plant Syst. Evol. 259(2-4): 249-258.

Zohary M. 1966. Flora Palaestina. 1. Israel Academy of Sciences and Humanities, Jerusalem. 